\title{
PENGARUH BERBAGAI EKSTRAK AKAR DALAM STIMULASI INFEKSI CENDAWAN MIKORIZA ARBUSKULA (CMA) PADA Tithonia diversifolia
}

\author{
Agustian $^{1)}$, Arwie Delfi, dan Lusi Maira \\ 1)Laboratorium Biologi Tanah $F$ akultas Pertanian U niversitas Andalas \\ Kampus Limau M anis, Padang (25163) telp. 0751-72773, F ax. 0751-777061 \\ Alamatkorespondensi, email: agustian@faperta.unand.ac.id
}

\begin{abstract}
In the first stage of arbuscular-mycorrhiza (AMF) fungi development on plant roots showed that root exudates, is a substance that determines the success of the establishment of mycorrhizal symbiosis. This secondary metabolites produced is intended to keep mold growth during the phase preinfection. Therefore, it is interesting to know whether to add the root extract of the plant could enhance CMA fungal infection in its host plant. The purpose of this study was to determine the type of root extract can stimulate CMA infection at the root and its influence on the growth of Tithonia diversifolia. This experiment used Completely Randomized Design (CRD) with 4 treatments and 3 replications, and continued with advanced test DNMRT at level 5\%. The treatments assayed were: control, Tris- $\mathrm{HCl}$ buffer $\mathrm{pH} 7$ (A), root extract of weed Imperata cylindrica (B); root extract of taro (C), and root extract of cassava (D). Base on the results obtained we concluded that the extract of the roots of weeds, taro and cassava does not give effect to the increased growth of Tithonia. However, the roots extract stimulated and had influenced on the percentage and intensity of AMF infection at the root of Tithonia and the number of spores obtained in the rhizosphere of Tithonia. In this case the root extract of taro showed the best stimulatory effect of infection with the percentage and intensity of infection are $99.3 \%$ and $30.59 \%$ consecutively with the number of spores found reach 113 spores/ $100 \mathrm{~g}$ soil.
\end{abstract}

Key words: Stimulation, arbuscular-mycorrhiza, root extract, Tithonia diversifolia

\section{PENDAHULUAN}

Cendawan mikoriza arbuskula (CMA) merupakan cendawan simbiotik obligat (artinya sumber karbon diperoleh dari tanaman inang untuk melengkapi siklus hidupnya) dan dalam hal ini tahapan pengenalan tanaman inang merupakan tahapan yang sangat menentukan bagi kelangsungan hidupnya. Spora CMA dalam tanah dapat saja berkecambah secara spontan jika lingkungannya mendukung akan tetapi hifa akan sangat terbatas pertumbuhannya tanpa tanaman inang. Jika keberadaan tanaman inang terlacak (Mosse, 1988) maka hifa akan membentuk percabangan yang banyak dan ini menjadi penanda dimulainya fase awal simbiosis atau dikenal dengan fase presimbiotik (Giovannetti et al. 1994, 1996).

sifat dan karakter faktor penentu dari tanaman yang merangsang terjadinya infeksi
Tithonia diversifolia sebagai tumbuhan semak yang sekarang ini umumnya digunakan sebagai pupuk hijau (Jama et al, 2000) dapat terinfeksi CMA dengan fekuensi infeksi yang tinggi (75-87\%) (Agustian, 2004), dan akar Tithonia yang terinfeksi CMA tersebut dapat digunakan sebagai inokulum bagi tanaman jagung (Agustian, 2011). Inokulasi dengan Glomus dan Gigaspora (Agustian et al , 2011), memperlihatkan Tithonia dapat terinfeksi oleh species CMA tersebut walaupun tidak memperlihatkan respon pada pertumbuhan vegetatifnya. Namun demikian belum bisa diketahui apakah ada efek stimulasi dari akar Tithonia yang menjadikannya terinfeksi CMA dengan frekuensi dan intensitas yang tinggi.

Infeksi tanaman inang oleh CMA dimulai dengan pembentukan appresorium pada permukaan akar oleh hifa eksternal yang berasal dari spora atau akar bermikoriza dalam tanah. Berbagai penelitian berusaha mengungkap akar tanaman inang. Hasil penelitian Carr et al, (1985) menunjukkan kultur sel tanaman 
Medicago sativa, Solanum tuberosum dan Triticum aestivum dapat menstimulasi pertumbuhan CMA. Nagahashi dan Douds (2004) di lain pihak menemukan sel-sel pembungkus tudung akar atau musilase akar dapat berfungsi sebagai stimulan bagi percabangan hifa Gigaspora gigantea.

Penelitian tentang fenomena simbiosis CMA sejauh ini terfokus terhadap peranan eksudat akar dan sejumlah penelitian menemukan adanya efek induksi dari eksudat akar tanaman inang terhadap percabangan dan perkembangan CMA (Nagahashi dan Douds, 2007). Sebaliknya eksudat akar yang bukan tanaman inang dari penelitian Gianinazzi-Pearson et al. (1989) dan Giovannetti et al.(1994), tidak memberikan pengaruh bagi terjadinya percabangan dan pertumbuhan hifa-hifa, dan seringkali menjadi inhibitor (Koide dan Schreiner, 1992)bagi perkembangan CMA.

Senyawa flavonoid diduga merupakan senyawa yang terlibat dalam berbagai fase perkembangan simbiosis karena merupakan senyawa utama yang sering ditemukan (Shaw et al., 2006). Senyawa ini ditemukan dalam eksudat akar tanaman dan diketahui berfungsi dalam interaksi mikroorganisme dengan tanaman (Fokom et al, 2010) dan memiliki efek induksi terhadap perkecambahan basidiospore cendawan ektomikoriza Suillus bovinus (Kikuchi et al (2007). Besserer et al. (2006) menemukan senyawa strigolactone yang berperan sebagai stimulan bagi perkecambahan benih tumbuhan parasit Striga (Bouwmeester et al., 2003) ternyata juga menginduksi perkecambahan spora, percabangan hifa dan pertumbuhan CMA.

Mengetahui bahan stimulan bagi perkecambahan dan infeksi perakaran tanaman inang oleh CMA akan memberikan banyak manfaat. Tujuan dari penelitian ini adalah untuk mengetahui jenis ekstrak akar yang memberikan stimulasi bagi infeksi CMA pada akar Tithonia serta mengetahui pengaruhnya terhadap pertumbuhan Tithonia.

\section{BAHAN DAN METODA}

Percobaan pot ini menggunakan media pasir kali yang sudah sterilkan. Biji Tithonia yang telah disterilkan merupakan bahan perbanyakan yang digunakan dalam penelitian. Cendawan Mikoriza Arbuskula campuran (Glomus sp dan Gigaspora sp) yang diperoleh dari Inhoro Parung bogor digunakan sebagai inokulum untuk infeksi Tithonia sedangkan bahan induksi yang dipakai sebagai perlakuan adalah ekstrak akar alang-alang, talas dan ubi kayu.

Rancangan percobaan yang digunakan dalam percobaan ini merupakan Rancangan Acak lengkap dengan uji lanjut DNMRT taraf 5\%. Perlakuan yang dicobakan adalah berbagai ekstrak akar tanaman yang proses pengekstraknya berpedoman dari penelitian Ocampo et al (1986) yang menggunakan buffer Tris- $\mathrm{HCl} \mathrm{pH}$ 7.0. Perlakuan yang dicobakan adalah: Larutan Tris$\mathrm{HCl} \mathrm{pH}$ 7,0 sebagai kontrol (A), ekstrak akar alang-alang (B), ekstrak akar talas (C), dan ekstrak akar ubi kayu (D). Pasir kali yang digunakan sebagai media tumbuh adalah sebanyak $1 \mathrm{~kg} /$ pot yang telah disterilkan dengan menggunakan autoklaf pada suhu $120^{\circ} \mathrm{C}$ selama $2 \times 60$ menit. Biji Tithonia disterilkan dengan menggunakan alcohol $70 \%$ agar terbebas dari mikroba patogen. Sebanyak 100 ml larutan buffer Tris-HCl pH 7,0 digunakan untuk mengekstrak akar seberat $5 \mathrm{~g}$. Inokulan CMA sebanyak \pm 100 spora ditaburkan di atas permukaan tanah dalam pot yang telah diisi $0,75 \mathrm{~kg}$ pasir dan selanjutnya ditutup dengan pasir sebanyak $0,25 \mathrm{~kg}$ yang masih tersisa.

Biji Tithonia ditanam sebanyak 5 biji per pot, dan setelah kecambah berumur 15 hari dilakukan induksi dengan pemberian ekstrak akar sebanyak $10 \mathrm{ml}$ per pot sebanyak 4 kali dengan interval pemberian selang 2 minggu. Ekstrak diberikan sampai Tithonia berumur 8 minggu. Pemeliharan dilakukan dengan melakukan penyiraman setiap hari menggunakan larutan Hyponex merah (2,5 g/10 lt aquades) sampai umur 4 minggu dan dilanjutkan dengan larutan Hyponex biru sampai umur 8 minggu. Panen dilakukan setelah tanaman berumur 2 bulan. Pengamatan terhadap tanaman dilakukan terhadap perkembangan tinggi tanaman, bobot basah dan kering batang dan akar, frekuensi dan intensitas infeksi CMA, jumlah spora serta serapan tanaman. Frekuensi infeksi dan intensitas CMA ditentukan sesuai prosedur yang dikemukakan Trouvelot et al (1985), dengan mengamati potongan-potongan akar yang telah diwarnai dengan Lactophenol Tryphan Blue dibawah mikroskop. Jumlah spora dalam tanah yang terbentuk akibat perlakuan dihitung 
menggunakan metoda penyaringan basah.

\section{HASIL DAN PEMBAHASAN}

Pertumbuhan Tithonia

Pemberian ekstrak akar tanaman berpengaruh tidak nyata terhadap tinggi tanaman begitu juga dengan jumlah daun Tithonia sampai umur 2 bulan setelah tanam (Tabel 1). Namun demikian dari data tersebut dapat dilihat bahwa tanaman tanpa pemberian ekstrak akar pertumbuhannya cenderung tidak sebaik tanaman yang diberi ekstrak akar. Perlakuan dengan ekstrak akar ubi kayu memiliki tinggi yaitu $24,43 \mathrm{~cm}$ tertinggi dari perlakuan lain walaupun masih berbeda tidak nyata dengan perlakuan kontrol dengan ketinggian hanya $21 \mathrm{~cm}$. Hal yang sama juga ditemukan untuk jumlah daun dimana pemberian ekstrak akar tanaman tidak memperlihatkan pengaruh yang nyata terhadap perkembangan jumlah daun.

Tabel 1. Data pengamatan tinggi dan jumlah daun Tithonia (umur 2 bulan)

\begin{tabular}{|l|ll|ll|}
\hline Perlakuan & $\begin{array}{l}\text { Tinggi } \\
\text { tanaman } \\
\text { rata-rata } \\
\text { (cm) }\end{array}$ & $\begin{array}{l}\text { Jumlah } \\
\text { daun rata- } \\
\text { rata } \\
\text { (helai) }\end{array}$ \\
\hline Kontrol & 21,00 a & 18,60 & a \\
\hline $\begin{array}{l}\text { Ekstrak akar } \\
\text { alang-alang }\end{array}$ & 21.40 a & 16,00 & a \\
\hline $\begin{array}{l}\text { Ekstrak akar } \\
\text { talas }\end{array}$ & 23.67 a & 19,30 & a \\
\hline $\begin{array}{l}\text { Ekstrak akar } \\
\text { ubi kayu }\end{array}$ & 24.43 a & 18,60 & a \\
\hline
\end{tabular}

Angka-angka yang diikuti oleh huruf kecil yang sama pada kolom yang sama berarti berbeda tidak nyata pada taraf $5 \%$.

Bobot basah dan bobot kering tanaman

Perlakuan ekstrak akar tanaman terlihat berpengaruh tidak nyata terhadap bobot basah dan bobot kering batang, daun dan akar Tithonia Tabel 2. Walaupun dari uji statistik berbeda tidak nyata tetapi bobot basah batang dan daun yang diberi ekstrak akar ubi kayu menunjukkan bobot tertinggi yaitu dengan rata-rata bobot basah batang dan daun 12,34 g/pot. Sementara itu bobot basah akar tertinggi ditemukan pada pemberian ekstrak akar talas yaitu dengan bobot basah rata-rata akar 7,97 g/pot. Pertambahan bobot basah tanaman menunjukkan adanya keterkaitan pertumbuhan vegetatif yaitu tinggi tanaman dan jumlah daun. Dimana semakin baik pertumbuhan vegetatif maka bobot basah juga akan semakin tinggi.

Bobot kering batang dan daun serta akar pada pemberian ekstrak akar ubi kayu ditemukan paling tinggi yaitu dengan ratarata bobot kering 2,81 g/pot untuk batang dan daun serta $0,87 \mathrm{~g} /$ pot untuk rata-rata bobot kering akar. Seperti halnya dengan bobot basah, bobot kering juga berkorelasi erat dengan pertumbuhan vegetatif tanaman seperti tinggi tanaman, jumlah daun tersebut. Rasio berat kering akar dengan batang tidak menunjukkan perbedaan yang nyata akibat perlakuan dengan ekstrak akar walaupun ada kecendrungan nilai rasio dengan pemberian ekstrak akar lebih tinggi dibanding kontrol. Hal ini menunjukkan bahwa ekstrak akar tidak menyebabkan adanya penumpukkan biomassa baik pada akar maupun batang. Menurut Tobar et al. (1999) peningkatan nilai rasio akar/batang mencerminkan nilai efektivitas mikorisasi. Perbaikan kualitas pertumbuhan akibat inokulasi CMA terlihat dari kekuatan, ketahanan dan perkembangan tanaman seperti ditemukan pada tanaman lada yang diinokulasi dengan $G$. intradices (AguileraGomez et al., 1999) dan zaitun (MeddadHamza et al, 2010)

Serapan hara N, P dan K Tithonia

Pemberian ekstrak akar tanaman berpengaruh nyata terhadap serapan $\mathrm{N}$ batang dan daun Tithonia tetapi tidak nyata untuk serapan $\mathrm{P}$ dan $\mathrm{K}$. Pada serapan $\mathrm{N}$ akar Tithonia berbeda tidak nyata tetapi berbeda nyata untuk serapan $\mathrm{P}$ dan $\mathrm{K}$ akar Tithonia seperti terlihat pada Tabel 3. Serapan N tertinggi batang dan daun ditemukan dengan pemberian ekstrak akar tanaman talas dengan ratarata $7 \mathrm{mg} /$ pot . Pada perlakuan yang sama juga ditemukan untuk serapan $\mathrm{N}$ tertinggi akar. Dari data ini dapat kita lihat, bahwa pemberian ekstrak akar lebih berpengaruh terhadap serapan hara pada akar dari pada serapan hara pada bagian atas tanaman (batang dan daun). 
Tabel 2. Pengaruh pemberian ekstrak akar tanaman terhadap bobot basah (BB) dan bobot kering (BK) batang dan daun serta akar Tithonia

\begin{tabular}{|c|c|c|c|c|c|c|}
\hline No. & Perlakuan & $\begin{array}{c}\text { BB } \\
\text { Batang } \\
\text { dan daun }\end{array}$ & $\begin{array}{l}\text { BB } \\
\text { akar }\end{array}$ & $\begin{array}{l}\text { BK batang } \\
\text { dan daun }\end{array}$ & BB akar & $\begin{array}{c}\text { Ratio BK akar } / \\
\text { BK batang dan } \\
\text { daun }\end{array}$ \\
\hline & & & \multicolumn{3}{|c|}{ (g/pot) } & \\
\hline 1 & Kontrol & 10,96 а & 7,19 a & $2,59 \mathrm{a}$ & $0,77 \mathrm{a}$ & $0,30 \mathrm{a}$ \\
\hline 2 & $\begin{array}{l}\text { Ekstrak akar } \\
\text { alang-alang }\end{array}$ & $10,65 \mathrm{a}$ & $7,69 \mathrm{a}$ & $2,47 \mathrm{a}$ & $0,80 \mathrm{a}$ & $0,33 a$ \\
\hline 3 & $\begin{array}{l}\text { Ekstrak akar } \\
\text { talas }\end{array}$ & $11,57 \mathrm{a}$ & 7,97 a & $2,59 \mathrm{a}$ & $0,86 \mathrm{a}$ & $0,34 a$ \\
\hline 4 & $\begin{array}{ll}\text { Ekstrak } & \text { akar } \\
\text { ubi kayu }\end{array}$ & $12,34 \mathrm{a}$ & 6,40 a & $2,81 \mathrm{a}$ & $0,87 \quad \mathrm{a}$ & $0,31 \mathrm{a}$ \\
\hline
\end{tabular}

Angka-angka yang diikuti oleh huruf kecil yang sama pada kolom yang sama berarti berbeda tidak nyata pada taraf $5 \%$.

Serapan P batang dan daun pada seluruh perlakuan sama yaitu dengan serapan $\mathrm{P}$ ratarata batang dan daun rata-rata $3,33 \mathrm{mg} /$ pot. Sedangkan serapan $\mathrm{P}$ cendrung tinggi pada akar terdapat pada tanaman yang diberi ekstrak akar alang-alang yaitu dengan serapan $\mathrm{P}$ rata-rata $1,06 \mathrm{mg} /$ pot. Serapan K batang dan daun cendrung tinggi pada pemberian ekstrak akar talas yaitu dengan serapan $\mathrm{K}$ sebesar $40 \mathrm{mg} /$ pot. Untuk serapan $\mathrm{K}$ akar tertinggi terdapat pada tanaman yang diberi ekstrak akar ubi kayu dengan serapan $\mathrm{K}$ sebesar $8 \mathrm{mg} /$ pot. Ketiga perlakuan yang diberi ekstrak akar berbeda nyata dengan kontrol yang tidak diberi ekstrak akar. Secara keseluruhan dari hasil analisis serapan hara N,P dan $\mathrm{K}$ dapat kita simpulkan rata-rata serapan hara Tithonia yang diberi ekstrak akar walaupun dari hasil uji statistik ada yang berbeda tidak nyata dengan perlakuan kontrol namun ketiga perlakuan yang menerima ekstrak akar meningkatkan serapan hara Tithonia.

Tabel 3. Pengaruh pemberian ekstrak akar tanaman terhadap serapan N, P, K batang dan daun serta akar Tithonia (mg/pot)

\begin{tabular}{|l|c|l|l|l|l|l|}
\hline \multicolumn{1}{|c|}{ Perlakuan } & $\begin{array}{c}\text { Serapan N } \\
\text { batang dan } \\
\text { daun }\end{array}$ & $\begin{array}{c}\text { Serapan P } \\
\text { batang dan } \\
\text { daun }\end{array}$ & $\begin{array}{c}\text { Serapan K } \\
\text { batang dan } \\
\text { daun }\end{array}$ & $\begin{array}{c}\text { Serapan N } \\
\text { akar }\end{array}$ & $\begin{array}{c}\text { Serapan P } \\
\text { akar }\end{array}$ & $\begin{array}{c}\text { Serapan K } \\
\text { akar }\end{array}$ \\
\hline Kontrol & $9,33 \mathrm{ab}$ & $3,00 \mathrm{a}$ & $33,33 \mathrm{a}$ & $1,26 \mathrm{a}$ & $0,43 \mathrm{~b}$ & $4,33 \mathrm{~b}$ \\
\hline $\begin{array}{l}\text { Ekstrak akar } \\
\text { alang-alang }\end{array}$ & $8,33 \mathrm{~b}$ & $3,33 \mathrm{a}$ & $30,00 \mathrm{a}$ & $2,00 \mathrm{a}$ & $1,06 \mathrm{a}$ & $6,67 \mathrm{a}$ \\
\hline $\begin{array}{l}\text { Ekstrak akar } \\
\text { talas }\end{array}$ & $17,00 \mathrm{a}$ & $3,33 \mathrm{a}$ & $40,00 \mathrm{a}$ & $2,67 \mathrm{a}$ & $0,80 \mathrm{a}$ & $7,67 \mathrm{a}$ \\
\hline $\begin{array}{l}\text { Ekstrak akar } \\
\text { ubi kayu }\end{array}$ & $14,33 \mathrm{a}$ & $3,33 \mathrm{a}$ & $36,67 \mathrm{a}$ & $2,57 \mathrm{a}$ & $0,93 \mathrm{a}$ & $8,00 \mathrm{a}$ \\
\hline
\end{tabular}

Angka-angka yang diikuti oleh huruf kecil yang sama pada kolom yang sama berarti berbeda tidak nyata pada taraf $5 \%$. 
Frekuensi dan intensitas infeksi CMA serta jumlah spora

Pemberian ekstrak akar tanaman berpengaruh nyata terhadap fekuensi dan intensitas infeksi CMA serta jumlah spora yang dalam tanah Tabel 4. Frekuensi infeksi pada perlakuan dengan ekstrak akar cenderung lebih tinggi dan berbeda nyata dibandingkan dengan perlakuan tanpa ekstrak akar. Ekstrak akar talas memberikan stimulasi infeksi CMA dengan persentase infeksi CMA sebesar 99,33 \%, tertinggi diantara perlakuan lainnya. Pada perlakuan ini juga kita temukan intensitas infeksi tertinggi yaitu 30,6 \% dengan jumlah spora mencapai 113,3 spora/ 100g tanah. Jika kita hubungkan data yang diperoleh pada Tabel $1,2,3$ dan 4 terlihat bahwa tingginya persentase infeksi dan intensitas infeksi tidak memberikan pengaruh terhadap pertumbuhan Tithonia, namun demikian berpengaruh terhadap serapan hara $\mathrm{N}, \mathrm{P}$ dan $\mathrm{K}$ terutama serapan pada akar tanaman. Penelitian ini menunjukkan bahwa ekstrak akar tanaman (alang-alang, talas dan ubi kayu) yang digunakan memberikan pengaruh yang nyata dalam stimulasi infeksi CMA pada akar Tithonia. Ketika jamur arbuskula endomycorrhizal merasakan adanya tanaman inang menurut Giovannetti et al (1994), hifa mengalami perubahan morfologis ditandai dengan percabangan hifa menjadi sangat banyak. Percabangan meningkatkan kemungkinan kontak fisik antara jamur dan akar, sebelum penetrasi jamur dalam korteks akar. Hal ini menunjukkan adanya faktor dalam eksudat akar yang mendorong respon tanaman (Becard et al, 1989; Nagahashi et al, 1999). Adanya pengaruh ekstrak akar ini juga dikemukakan oleh Azcon and Ocampo (1984) dan Nair et al (1991) pada Trifolium repens. Dipihak lain Carr et al, (1985) menemukan bahwa ekstrak akar Medicago sativa, Triticum aestivum, dan Solanum tuberosum dapat menstimulasi perkecambahan spora dan percabangan hifa CMA. Penelitian Nagahashi dan Douds (1999) dan (2000) menemukan bahwa akar Daucus carota, Lycopersicon esculentum ternyata berfungsi sebagai branching factor (BF) bagi spora G . gigantea.

Substansi dari eksudat akar yang dapat menjadi stimulan untuk perkembangbiakan dan kolonisasi mikroba diduga merupakan senyawa flavonoid karena senyawa ini sering ditemukan dalam berbagai fase perkembangan simbiosis (Shaw et al, 2006), antara lain strigolactone yang ditemukan Besserer et al. (2006) yang berperan sebagai stimulan dalam interaksi mikroorganisme dengan tanaman yang juga memiliki efek induksi (Kikuchi et al, 2007) terhadap perkecambahan basidiospore cendawan ektomikoriza S. bovinus.

Dengan adanya infeksi CMA yang dapat dipercepat akan memberikan

Tabel 4. Pengaruh pemberian ekstrak akar tanaman terhadap frekuensi dan intensitas infeksi CMA serta jumlah spora dalam tanah

\begin{tabular}{|c|c|c|c|}
\hline Perlakuan & $\begin{array}{l}\text { Frekuensi } \\
\text { infeksi CMA }\end{array}$ & $\begin{array}{c}\text { Intensitas } \\
\text { infeksi CMA }\end{array}$ & Jumlah spora \\
\hline & & 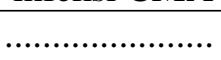 & ..Spora/ $100 \mathrm{~g}$ tanah.. \\
\hline Kontrol & $23,0 \mathrm{~b}$ & 3,9 & $90,7 \mathrm{a}$ \\
\hline $\begin{array}{l}\text { Ekstrak akar alang- } \\
\text { alang }\end{array}$ & $48,3 a b$ & $2,0 \quad b$ & $44,0 \mathrm{~b}$ \\
\hline Ekstrak akar talas & 99,3 a & 30,6 a & $113,3 \mathrm{a}$ \\
\hline $\begin{array}{l}\text { Ekstrak akar ubi } \\
\text { kayu }\end{array}$ & $37,7 \mathrm{~b}$ & $0,7 \quad b$ & $72,0 \mathrm{a} b$ \\
\hline
\end{tabular}

Angka-angka yang diikuti oleh huruf kecil yang sama pada kolom yang sama berarti berbeda tidak nyata pada taraf $5 \%$. 
keuntungan bagi pertumbuhan dan perkembangan tanaman inang serta meningkatkan kemampuannya dalam menyerap unsur hara dari dalam tanah. Namun demikian tidak semua jenis tanaman dapat memberikan respon positif terhadap inokulasi CMA, seperti yang ditemukan pada percobaan ini. Hal ini kelihatannya sangat tergantung dari tingkat mycorrhizal dependency (ketergantungan akan mikoriza) dari tanaman. Smith dan Read (2008) mengemukakan bahwa tidak ada ikatan yang khas antara CMA dengan tanaman inang. Menurut Scervino et al, (2005), CMA tidak menghendaki tanaman inang yang spesifik namun CMA cendrung menyukai tanaman inang tertentu. Ada dugaan bahwa pola infeksi diatur oleh tanaman inang namun demikian adanya kompetisi antara spesies CMA dalam kolonisasi akar tanaman (Pearson et al. 1993; Jacquot-Plumey et al. 2001) ikut menentukan keberhasilan simbiosis. Tanaman yang mempunyai bulu akar sedikit umumnya jauh lebih peka dan tanggap dibandingkan tanaman yang memiliki bulu akar banyak (Boukcim et al, 2001) dan umur akar menurut Tawaraya et al (2007) juga menentukan jumlah apresorium yang terbentuk di akar. Menggunakan teknik Polymerized Chain Reaction (PCR), Sharrock et al (2004) membuktikan bahwa Tithonia dapat diinfeksi oleh berbagai species CMA terutama dari keluarga Glomaceae. Hal ini menunjukkan bahwa pada saat yang bersamaan ada banyak species CMA yang dapat menginfeksi akar Tithonia dan tingkat kompetisi antara sesama jamur CMA (penggunaan inokulum campuran) agaknya dalam hal penelitian ini menyebabkan tidak memunculkan respons Tithonia.

\section{KESIMPULAN DAN SARAN}

Dapat disimpulkan bahwa pemberian ekstrak akar tanaman alang-alang, talas dan ubi kayu tidak memberikan pengaruh terhadap peningkatan pertumbuhan Tithonia. Namun demikian pemberian ekstrak akar tanaman memberikan pengaruh stimulasi terhadap frekuensi dan intensitas infeksi CMA pada akar Tithonia serta jumlah spora pada tanah perakaran.
Dalam hal ini ekstrak akar talas menunjukkan pengaruh stimulasi terbaik dengan persentase infeksi 99,3\% dan intensitas infeksi 30,6 \% serta jumlah spora 113 spora/ $100 \mathrm{~g}$ tanah. Diperlukan penelitian lanjutan untuk mencari substansi dalam ekstrak akar talas yang dapat menstimulir infeksi CMA disamping mencari kondisi yang tepat untuk mendapatkan efek yang optimal bagi pertumbuhan Tithonia.

\section{DAFTAR PUSTAKA}

Aguilera-Gomez, L., F.T. Davis Jr., S.A. Duray, L. Phavaphutanon and V. Olalde-Portugal, 1999. Influence of phosphorus and endomycorrhiza (Glomus intraradices) on gas exchange and plant growth of Chile ancho pepper (Capsicum annuum cv. San Luis). Photosynthetica, 36: 441-449

Agustian. 2004. Keragaman Cendawan Mikoriza Arbuskula (CMA) pada tithonia (Tithonia diversifolia) yang tumbuh pada berbagai ketinggian tempat di Sumatera Barat. J urnal Stigma Vol XI No. 4. p. 85-92

Agustian, 2011. Pemanfaatan Akar Tithonia Diversifolia Terinfeksi Cendawan Mikoriza Arbuskula Sebagai Inokulum Terhadap Pertumbuhan dan Produksi Jagung. J . Solum 8 (1) 2011: 27-33

Agustian, Mutia Faiza, Lusi Maira. 2011. Respon Pertumbuhan Tithonia Diversifolia Terhadap Inokulasi Cendawan Mikoriza Arbuskula (CMA). J. Solum 8 (2): 70-77

Azcon, R. and J. A. Ocampo. 1984. Effect of root exudation on VA mycorrhizal infection at early stages of plant growth. Plant and Soil 82,133-138

Azcon-Aguilar, C., D. N. RodriguezNavarro and J. M. Barea. 1981. Effects Of Ethrel On The Formation and Responses To VA Mycorrhiza In Medicago And Triticum. Plant and Soil 60, 461-468 (1981).

Besserer, A., V. Puech-Pages, P. Kiefer, V. Gomez-Roldan, A. Jauneau, S. Roy, J.C. Portais, C. Roux, G. Becard, and N. Sejalon-Delmas. 2006. Strigolactones stimulate arbuscular mycorrhizal fungi by activating mitochondria. PLoS Biology. 4(7): p. e226. 
Bolton, H.Jr, J.K. Fredrickson and L.F. Elliot. 1993. Microbial Ecology of Rhizosphere. In Soil Microbial Ecology (Editor: Meeting. F. Blaine, Jr. Enviromental Sciences Pacific Northwest Laboratories, Richland. Volume 8 Washington. USA. p31 - 34

Boukcim, H., L. Pages, C. Plassard and D. Mousain. 2001. Root system architecture and receptivity to mycorrhizal infection in seedlings of Cedrus atlantica as affected by nitrogen source and concentration. Tree Physiol. $21,109-115$

Bouwmeester, H.J., R. Matusova, S. Zhongkui, and M.H. Beale. 2003. Secondary metabolite signalling in hostparasitic plant interactions. Current Opinion in Plant Biol., 6(4): p. 358-364.

Carr, G.R., M.A. Hinkley, F. Tacon, C.M. Hepper, M.G.K. Jones, and E. Thomas. 1985. Improved hyphal growth of two species of vesicular-arbuscular mycorrhizal fungi in the presence of suspension-cultered plant cells. New Phytol., 1985. 101(3): p. 417-426.

Dakora, F.D., and D.A. Phillips. 2002. Root exudates as mediators of mineral acquisition in low-nutrient environments. Plant and Soil 245: 3547, 2002.

Duddridge, J.A. 1986. Specificity and Recognition in Mycorrhizal associations. Mycorrhizae : Proceeding Physiology and Genetics. Les Mycorhizoes : Physiologie et Genetique. INRA. Paris. 13 halaman

Fokom, R., W. L.Nana, S. Tchameni, and D. Nwaga. 2010. Arbuscular Mycorrhizal Fungi (AMF) Colonisation and Rhizobia nodulation of Cowpea as Affected by Flavonoid Application. Res. J. Agric. \& Biol. Sci., 6(6):1015-1021

Gianinazzi-Pearson, V., B. Branzanti, and S. Gianinazzi. 1989. In vitro enhancement of spore germination and early hyphal growth of a vesicular-arbuscular mycorrhizal fungus by host root exudates and plant flavonoids. Symbiosis. 7: p. 243-255.

Jama, B., C.A. Palm, R.J. Buresh, A. Niang, C. Gachengo, G. Nziguheba, B.
Amadalo.2000. Tithonia diversifolia as a green manure for soil fertility improvement in western Kenya: a review. Agrofor Syst 49:201-221

Koide, R.T. and R.P. Schreiner, 1992. Regulation of the vesicular arbuscular mycorrhizal symbiosis. Ann. Rev. of plant physiol.and plant mol.biol. 43: p. 557-581.

Kikuchi, K., N. Matsushita, K. Suzuki and T. Hogetsu. 2007. Flavonoids induce germination of basidiospores of the ectomycorrhizal fungus Suillus bovines. Mycorrhiza (2007) 17:563-570 DOI 10.1007/s00572-007-0131-8

Meddad-Hamza, A., A. Beddiar, A. Gollotte, M. C. Lemoine, C. Kuszala and S. Gianinazzi. 2010. Arbuscular mycorrhizal fungi improve the growth of olive trees and their resistance to transplantation stress. Afric. J. of Biotech. Vol. 9(8), pp. 1159-1167

Medina, M. J. H., H. Gagnon, Y. Piche, J. A. Ocampo,J.M.G. Garrido, and H. Vierheilig. 2003. Root colonization by arbuscular mycorrhizal fungi is affected by the salicylic acid content of the plant. Plant Sci. 164 : 993-998

Mosse, B., 1988. Some studies relating to "independent" growth of vesiculararbuscular endophytes. Canadian journal of botany, 66: p. 2533-2540.

Nair, M.G., R.G. Safir,AND J. O. Siqueira. 1991. Isolation and Identification of Vesicular-Arbuscular MycorrhizaStimulatory Compounds from Clover (Trifolium repens) Roots. Appl. and Env. Microbiol., Vol. 57, No.2 p. 434439

Nagahashi, G. and D.D. Douds, Jr., 2004. Isolated root caps, border cells, and mucilage from host roots stimulate hyphal branching of the arbuscular mycorrhizal fungus, Gigaspora gigantea. Mycol. Res., 108: p. 1079-88.

Nagahashi, G. and D. Douds, Jr. 2007. Separated components of root exudate and cytosol stimulate different morphologically identifiable types of branching responses by arbuscular mycorrhizal fungi. Mycol. Res., $111 \mathrm{p}$. 487-92. 
Ocampo, J. A. and R. Azcon. 1985. Relationship between the concentration of sugars in the roots and VA mycorrhizal infection. Plant and Soil 86, 95-100.

Ocampo, J.A., F.L. Cardona and F.EL.Atrach. 1986. Effects of Root Extracts of Non Host Plants on VA Mycorrhizal Infection and Spore Germination. Mycorrhizae : Physiology and Genetics-Les Mycorhizes : Physiologie et Genetique. INRA. Paris. 4 halaman

Scervino, J.M., M.A. Ponce, R. ErraBassells, J. Bompadre, H. Vierheilig, J.A. Ocampo, and A. Godeas, The effect of flavones and flavonols on colonization of tomato plants by arbuscular mycorrhizal fungi of the genera Gigaspora and Glomus. Can.J. Microbiol., 2007. 53(6): p. 702-9.

Shaw, L.J., P. Morris, and J.E. Hooker. 2006. Perception and modification of plant flavonoid signals by rhizosphere microorganisms. Environ. Microbiol.. 8(11): p. 1867-1880.

Sharrock, R.A., F.L. Sinclair, C. Gliddon, I.M. Rao, E. Barrios, P.J. Mustonen, P. Smithson,
D.L. Jones, D.L. Godbold. 2004. A global Assessment using PCR techniques of mycorrhizal fungal populations colonizing Tithonia diversifolia. Mycorrhiza 14 (2), p.103-109

Smith, S. and D. Read. 1997. Mycorrhizal symbiosis. Academic Press, New York, 1997.

Tawaraya, K., S. Watanabe , H. Vierheilig and T. Wagatsuma. 2007. Formation of appressoria by the arbuscular mycorrhizal fungus Gigaspora margarita on roots of Allium cepa is linked with root age Mycoscience 48:305-308 DOI 10.1007/s10267-007-0367-3

Tobar, R.M., R. Azcon and J.M. Barea, 1999. The improvement of plant $\mathrm{N}$ acquisition from an ammonium treated drought stressed soil by the fungal symbionts in Arbuscular mycorrhizae. Soil Biol. Fert., 9: 1-8.

Trouvelot, A.J., L Kough dan V. GianinazziPearson. 1985. Measure du Taux de mycorrhization vesicle arbuscular d'un systeme radiculaire. Recherche de méthodes d'estimation ayant une signification fonctionnelle. Proc. of $1^{\text {st }}$ European Symposium on Mycorrhizae, p.217-222 